\title{
Scientific and academic journals in the Philippines: status and challenges
}

\author{
Evelyn Mae Tecson-Mendoza, ${ }^{1,2}$ \\ ${ }^{1}$ Institute of Plant Breeding, College of Agriculture, University of the Philippines Los Baños, Laguna; ${ }^{2}$ National Academy of \\ Science and Technology Philippines, Manila, Philippines
}

\section{Abstract}

As of July 2015, 28 Philippine scientific journals out of 777 Philippine scholarly journals are listed in the master journal lists of Thomson Reuters (TR), Scopus, or both. Of these scientific journals, thirteen are published by universities, two by government institutions, ten by professional organizations and three by private for-profit or non-profit organizations. Nineteen of these journals are over 25 years old, with the Philippine Journal of Science and the Philippine Agricultural Scientist being the oldest at 108 and 103 years in publication, respectively. Scientific journals in the Philippines, like other countries in Asia, face various increasing challenges. Among these challenges are getting listed in the master journal lists and citation databases of TR, Scopus, or both; obtaining funding; reaching a wider readership; attaining higher impact factors; competing for papers; and increased submission of manuscripts from outside the country. To promote the improvement of local journals, the National Academy of Science and Technology Philippines has given outstanding publication awards for scientific papers published in local journals for the past two decades. The Philippine Commission on Higher Education has accredited local journals that are included in either TR and Scopus journal master lists, and provides monetary incentives to accredited journals. Training workshops on scientific article writing and editorial management are conducted for researchers and editors by universities and professional and government organizations. A network of Philippine science editors has been formed to work together to upgrade and modernize selected journals to international standards.

Keywords

Received: July 16, 2015

Accepted: August 8, 2015

Correspondence to

Evelyn Mae Tecson-Mendoza

emtmendoza@gmail.com

ORCID

Evelyn Mae Tecson-Mendoza

http://orcid.org/0000-0002-5397-4445
Accreditation; Citation databases; Impact factor; Philippine journals

\section{Introduction}

The Philippines has a century-old history of scientific and academic publications. Two journals, the Philippine Journal of Science (PJS) and the Philippine Agricultural Scientist (PAS) are 
108 and 103 years in publication, respectively. The PJS was established in 1906 by the Bureau of Science (now the Department of Science and Technology, DOST), which had earlier published its research results in a series of bulletins. The PJS initially covered topics on agricultural and mineral resources and eventually included tropical medicine. On the other hand, the Philippine Agriculturist and Forester (now PAS) was founded by the student body of the College of Agriculture and Forestry, University of the Philippines (UP) at its Los Baños campus in 1911. The publication was renamed the Philippine Agriculturist and its management transferred to the college faculty in 1918, and its present name was adopted in 1999. Initially, PJS and PAS obtained their research articles from their constituencies, but eventually they began to receive and publish articles from other agencies and institutions within and outside of the country. In addition to publishing original research articles, the Philippine Agriculturist chronicled the growth and development of UP, as well as Philippine agriculture [1]. On behalf of UP, the Philippine Agriculturist won the Diploma D'Honneur by the International Jury in Paris for its volumes XIV and XVIII in 1932.

The Acta Medica Philippina, the official journal of the UP College of Medicine and College of Health, was first published in 1939. For many years, this journal was recognized as the primary medical journal of the Philippines and, like PJS and PAS, was widely circulated in libraries in Asia and the US. It served as a rich resource for articles on tropical diseases and local Philippine medical conditions, such as the rotavirus enteropathies and the famous Rotor syndrome. The Acta Medica Philippina declined in the late 1960s due to decreasing submission of papers, which might have resulted from an increase in the number of specialty medical journals. In 2003, the Acta was relaunched and later chosen as the National Health Science Journal by the DOST and the Philippine Council for Health Research and Development [2]. In the education field, the Journal of Philippine Education served the education sector from 1918 and ceased publication with its 31st volume in 1953 [3].

As of 2014, 777 scientific and scholarly Philippine journals were listed in the ISSN Directory of Journals from 1981 to 2013 [4]. Scientific journals in the Philippines, like other countries in Asia, face increasing challenges. This paper analyzes and discusses the status and challenges of Philippine science journals, which include getting listed by leading citation databases; obtaining funding; reaching a wider readership; attaining higher impact factors; competing for papers; and, in general, meeting international standards.

\section{Status and Profile of Selected Philippine Scientific Journals}

A large majority (87\%) of the 777 Philippine scientific and academic journals are published by higher education institutions, and the remainder by professional organizations $(12 \%)$ and government institutions (1.5\%) [4]. Of these, only 28 journals (4\% of the total number) are listed in the Thomson Reuters (TR) or Scopus master journal lists, or both (Table 1) [5].

As with most journals, Philippine scientific journals have aimed to be listed in international citation databases. Based on the journal master lists of TR and Scopus [6,7], eight Philippine journals are listed in both master lists, while an additional eight are listed in TR and a further twelve are listed in Scopus master lists (Table 1). Of the sixteen journals listed in the TR master list, only four are included in the Science Citation Index Expanded; namely, PAS, Journal of Environmental Science and Management, the Philippine Journal of Crop Science and Asia Life Sciences. Both PAS and Journal of Environmental Science and Management are journals of UP Los Baños. On the other hand, three journals in the social sciences, Philippine Political Science Journal, Asian and Pacific Migrayion Journal, and The Asia-Pacific Education Researcher (TAPER) are included in the Social Sciences Citation Index (SSCI). Among the medical journals, the following are listed in the Scopus master list: Acta Medica Philippina, the Philippine Journal of Internal Medicine, Philippine Journal of Nursing, Philippine Journal of Surgical Specialties, and the Philippine Journal of Obstetrics and Gynecology. Only nine of the 28 journals have an impact factor ranging from 0.059 to 0.793 , with TAPER and PAS having the highest impact factor values.

Two (7\%) of these journals are more than 100 years old. Seven (25\%) are between 50-99 years old, $10(36 \%)$ are $25-49$ years old, six (21\%) are 10-24 years old, and three (11\%) are 5-9 years old. Only eight of these journals publish four issues per volume per year. One journal has three issues, fourteen publish two issues, and five publish only one issue, per volume.

Of the 28 journals, thirteen are based at and published by universities (five public and eight private universities), two by government institutes, ten by professional organizations and three by private for-profit or non-profit organizations (Table 1). It should be noted that three journals are published for their organizations by international publishers. These are TAPER, published for Dela Salle University by Springer; the Philippine Political Science Journal, published by Taylor \& Francis for the Philippine Political Science Association; and the Asian and $\mathrm{Pa}$ cific Migration Journal, published for the Scalabrini Migration Centre by SAGE Journals.

Publication of papers from outside the country is high percentage for only 11 Philippine journals, and equates to $\geq 50 \%$ 
Table 1. Summary of Philippine scientific and academic journals listed in the journal master lists of Thomson Reuters, Scopus, or both

\begin{tabular}{|c|c|c|c|c|c|c|c|c|c|}
\hline & Title of journal & $\begin{array}{l}\text { Launching } \\
\text { year }\end{array}$ & $\begin{array}{l}\text { No. of } \\
\text { issues/ } \\
\text { year }\end{array}$ & Publisher & $\begin{array}{l}\text { Thomson } \\
\text { Reuters }\end{array}$ & Scopus & $\begin{array}{l}\text { Type of } \\
\text { publisher }\end{array}$ & $\begin{array}{c}\text { Articles } \\
\text { abroad } \\
(\%)^{a)}\end{array}$ & $\begin{array}{l}\text { Impact } \\
\text { factor in } \\
2013\end{array}$ \\
\hline 2 & $\begin{array}{l}\text { Philippine Agricultural } \\
\text { Scientist }\end{array}$ & 1911 & 4 & $\begin{array}{l}\text { University of the } \\
\text { Philippines Los Baños }\end{array}$ & $\stackrel{\times}{\mathrm{SCIE}}$ & $x$ & University & 65 & 0.368 \\
\hline 4 & $\begin{array}{l}\text { Philippine Political } \\
\text { Science Journal }\end{array}$ & 1974 & 2 & $\begin{array}{l}\text { Philippine Political Science } \\
\text { Association with Taylor \& } \\
\text { Francis from } 2012\end{array}$ & $\stackrel{\times}{\mathrm{SSCl}}$ & $x$ & $\begin{array}{l}\text { Professional } \\
\text { organization }\end{array}$ & 25 & 0.294 \\
\hline 5 & $\begin{array}{l}\text { Journal of Environmental } \\
\text { Science and Management }\end{array}$ & 1987 & 2 & $\begin{array}{l}\text { University of the Philippines } \\
\text { Los Baños }\end{array}$ & $\stackrel{\times}{S C I E}$ & $x$ & University & 20 & 0.103 \\
\hline 8 & $\begin{array}{l}\text { The Asia Pacific } \\
\text { Education Researcher }\end{array}$ & 1991 & 4 & $\begin{array}{l}\text { Springer (De La Salle } \\
\text { University, founder) }\end{array}$ & $\stackrel{\times}{\mathrm{SSCl}}$ & $x$ & $\begin{array}{l}\text { Private } \\
\text { University }\end{array}$ & 100 & 0.793 \\
\hline 9 & $\begin{array}{l}\text { Philippine Journal of } \\
\text { Crop Science }\end{array}$ & 1975 & 3 & $\begin{array}{l}\text { Crop Science Society of } \\
\text { the Philippines }\end{array}$ & $\stackrel{\times}{S C I E}$ & & $\begin{array}{l}\text { Professional } \\
\text { organization }\end{array}$ & 12 & 0.039 \\
\hline 10 & Philippine Entomologist & 1986 & 2 & $\begin{array}{l}\text { Philippine Association of } \\
\text { Entomologists }\end{array}$ & $x$ & & $\begin{array}{l}\text { Professional } \\
\text { organization }\end{array}$ & 0 & 0 \\
\hline 11 & Sylvatrop & 1990 & 2 & $\begin{array}{l}\text { Ecosystem Research and } \\
\text { Development Bureau, DENR }\end{array}$ & $x$ & & Government & 0 & 0 \\
\hline 12 & Asian Journal of Biodiversity & 2010 & 1 & Liceo de Cagayan University & $x$ & & University & 0 & 0 \\
\hline 15 & Silliman Journal & 1954 & 2 & Silliman University & $x$ & & $\begin{array}{l}\text { Private } \\
\text { University }\end{array}$ & NA & 0 \\
\hline 16 & The Philippine Scientist & 1964 & 1 & University of San Carlos & $x$ & & $\begin{array}{l}\text { Private } \\
\text { University }\end{array}$ & 30 & 0 \\
\hline 17 & $\begin{array}{l}\text { SABRAO Journal of } \\
\text { Breeding and Genetics }\end{array}$ & 1968 & 2 & $\begin{array}{l}\text { Society of for the } \\
\text { Advancement of Breeding } \\
\text { Research in Asia and } \\
\text { Oceania }\end{array}$ & & $x$ & $\begin{array}{l}\text { Professional } \\
\text { organization }\end{array}$ & 95 & 0.230 \\
\hline 18 & Kritika Kultura & 2002 & 1 & Ateneo de Manila University & & $x$ & $\begin{array}{l}\text { Private } \\
\text { University }\end{array}$ & 8 & 0 \\
\hline 19 & $\begin{array}{l}\text { DLSU Business and } \\
\text { Economics Review }\end{array}$ & 1988 & 2 & De la Salle University & & $x$ & $\begin{array}{l}\text { Private } \\
\text { University }\end{array}$ & 35 & 0 \\
\hline 20 & ACTA Medica Philippina & 1939 & 4 & $\begin{array}{l}\text { University of the Philippines } \\
\text { Manila }\end{array}$ & & $x$ & University & 0 & 0 \\
\hline
\end{tabular}


Table 1. Continued

\begin{tabular}{|c|c|c|c|c|c|c|c|c|c|}
\hline & Title of journal & $\begin{array}{l}\text { Launching } \\
\text { year }\end{array}$ & $\begin{array}{l}\text { No. of } \\
\text { issues/ } \\
\text { year }\end{array}$ & Publisher & $\begin{array}{c}\text { Thomson } \\
\text { Reuters }\end{array}$ & Scopus & $\begin{array}{l}\text { Type of } \\
\text { publisher }\end{array}$ & $\begin{array}{c}\text { Articles } \\
\text { abroad } \\
(\%)^{\text {a) }}\end{array}$ & $\begin{array}{l}\text { Impact } \\
\text { factor in } \\
2013\end{array}$ \\
\hline 21 & Humanities Diliman & 2000 & 2 & $\begin{array}{l}\text { University of the Philippines } \\
\text { Diliman }\end{array}$ & & $x$ & University & 0 & 0 \\
\hline 22 & $\begin{array}{l}\text { Philippine Studies: Historical } \\
\text { and Ethnographic } \\
\text { Viewpoints (formerly } \\
\text { Philippine Studies) }\end{array}$ & 1953 & 4 & Ateneo de Manila University & & $x$ & $\begin{array}{l}\text { Private } \\
\text { University }\end{array}$ & 17 & 0 \\
\hline 23 & ACTA Manilana & 1965 & 1 & University of Santo Tomas & & $x$ & $\begin{array}{l}\text { Private } \\
\text { University }\end{array}$ & & 0 \\
\hline 24 & $\begin{array}{l}\text { Philippine Journal of } \\
\text { Internal Medicine }\end{array}$ & 1963 & 4 & $\begin{array}{l}\text { Philippine College of } \\
\text { Physicians }\end{array}$ & & $\begin{array}{c}\times \\
\text { (active) }\end{array}$ & $\begin{array}{l}\text { Professional } \\
\text { organization }\end{array}$ & 0 & NA \\
\hline 25 & $\begin{array}{l}\text { Philippine Journal of Nursing } \\
\text { (started as Filipino Nurse } \\
\text { and renamed PJN in 1953) }\end{array}$ & 1926 & 2 & Philippine Nurses Association & & $x$ & $\begin{array}{l}\text { Professional } \\
\text { organization }\end{array}$ & 15 & NA \\
\hline 26 & $\begin{array}{l}\text { Philippine Journal of } \\
\text { Obstetrics \& Gynecology }\end{array}$ & 1976 & 4 & $\begin{array}{l}\text { Philippine Obstetrical and } \\
\text { Gynecological Society }\end{array}$ & & $x$ & $\begin{array}{l}\text { Professional } \\
\text { organization }\end{array}$ & NA & NA \\
\hline 27 & $\begin{array}{l}\text { Philippine Journal of Surgical } \\
\text { Specialties (started as } \\
\text { Philippine Journal of } \\
\text { Surgery, Phil J of Surgery } \\
\text { and Surgical Specialties) }\end{array}$ & 1946 & 4 & Philippine College of Surgeons & & $x$ & $\begin{array}{l}\text { Professional } \\
\text { organization }\end{array}$ & NA & NA \\
\hline 28 & Philosophia (Philippines) & 1999 & 2 & $\begin{array}{l}\text { Philippine National } \\
\text { Philosophical Research } \\
\text { Society }\end{array}$ & & $x$ & $\begin{array}{l}\text { Professional } \\
\text { organization }\end{array}$ & 50 & 0 \\
\hline
\end{tabular}

SCIE, Science Citation Index Expanded; SSCI, Social Sciences Citation Index; NA, data not available.

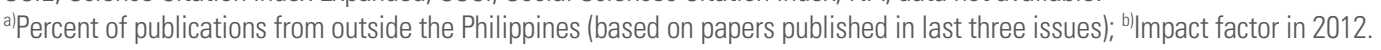

for five and $25 \%-49 \%$ for six journals.

\section{Challenges Facing Philippine Journals}

The challenges facing scientific and academic journals in the Philippines are both local and international in nature. These challenges relate to (1) the proliferation of journals and related problems, such as competition for papers and sub-par journals; (2) journal funding and operation; (3) getting listed or accredited in major citation databases; (4) competition for papers; (5) reaching a wider and bigger readership and paper contribution from outside the country; and (6) meeting international standards for academic journal publications.

\section{Proliferation of Journals}

Of the 777 scientific and scholarly journals in the Philippines, $86 \%$ were established after the year 2000, which may have been a response to satisfy the Commission on Higher Education (CHED) requirements for increased research publications and incentives for journal accreditation [4]. These journals usually contain only contributions from their own researchers who, to a certain extent, are forced to submit their papers in their university's journal. Thus, researchers are unable to publish their work in other, better-established journals in the country or abroad. Moreover, many of these university-based journals are unable to comply with high journal quality requirements, foremost of which is rigorous peer review; thus, the resulting journal papers and journals are often sub-par in quality [4] and do not qualify to be listed in the TR or Scopus journal master lists.

\section{Funding and Operation}

Most Philippine journals have limited budgets. They obtain their funds to support publication and related expenses from the government and/or private sector grants, university/institution budgets, subscriptions, and membership funds (in case of journals of professional organizations). Another major limitation is the lack of regular staff for most journals, which are staffed part-time by the organizations' members. Only a few 
journals have their own regular staff, such as the PAS and the PJS, with four and one regular staff members, respectively.

\section{Accreditation in Major Citation Databases}

In the Philippines, listing in either the TR or Scopus master journal lists will qualify journals for accreditation by CHED and monetary incentives [8]. Scientific papers published in such journals also qualify for awards with monetary incentives in several universities, such as the UP system, Mindanao State University, and others, and in government research institutes such as those of the DOST.

\section{Competition for Papers}

The number of published articles (about 1,200 in 2011) from the Philippines has been much lower than those from other Association of South East Asian Nations (ASEAN) countries [9]. Thus, Philippine journals have to compete for a smaller number of papers from local scientists, who may prefer to submit their papers to higher-impact journals outside the country. In addition, this low number of published papers does not include those published in local journals that are not listed in the TR or Scopus master journal lists.

\section{Reaching a Wider and Bigger Readership and Obtaining Impact Factor}

With the advent of the Internet, many Philippine journals have created websites and made their issues available both online and in print, or online only. Several offer delayed open access, while a few are open access without any charges for article publication. Those without their own websites have joined portals for journals such as UPLB Journals Online, Philippine Journals Online, E-International Journals of Academic and Scientific Research, and Philippine-e Journals, among others.

\section{Meeting International Standards for Academic Journal Publications}

In addition to being included in the top citation databases, there are new standards that journals must attain. These include adoption and/or use of the following: (1) digital object identifiers (DOIs) for journal articles and other publications, (2) a funding registry, (3) identification of current article status, (4) checking for plagiarism, and (5) author identification. The DOI was the first service offered by CrossRef, which now offers more services (including CrossCheck, CrossMark, FundRef, Text and Data Mining, and CrossRef Metasearch) [10]. Inclusion in a journal database such as PubMed Central is even more important for increasing readership than open access and citations are [11]. No Philippine biomedical journals are listed in established journal databases such as PubMed.

\section{Efforts to Meet International Standards of Scientific Journals}

For the past two decades, the National Academy of Science and Technology Philippines (NAST PHL) has given awards to outstanding papers published in Philippine scientific journals to encourage researchers to publish their high-quality papers in local journals and further improve these journals. On the other hand, since 2009 CHED has accredited local journals based on compliance with internationally-accepted standards and practice of refereeing and peer review. CHED accreditation awards for journals included in TR or Scopus master journal lists provide 200,000 Philippine peso (about 4,440 US dollars) per year for three years [12]. In 2012, CHED accredited 11 journals with a total budget of 2.2 million Philippine peso (50,000 US dollars) for one year for a total of 6.6 million Philippine peso (USD 150,000) for three years. This pales in comparison with the 5 million US dollars support provided to the Korean Federation of Science and Technology Societies for journal publications by the Korean government [13].

Various organizations have also provided training to editors on scientific journal management and to researchers on writing scientific articles. Moreover, training on preparing research proposals and conduct of research has been regularly conducted to upgrade the knowledge and skills of researchers.

In a meeting organized in October 2014 by NAST PHL, the editors and staff of 18 leading journals in the Philippines discussed their needs, difficulties, and goals to determine means and mechanisms by which these journals could be improved to meet international standards. Some of the recommendations were as follows: (1) formation of a network of editors and/or scientific and academic Philippine journals; (2) creation of a common portal for Philippine journals to be linked to journal websites; (3) harmonization of CHED and DOST policies on journals; (4) indexing of Philippine journals and published articles; (5) conduct of training courses on management of journals, editing, new international standards, writing scientific articles, etc.; and (6) greater financial support for selected scientific and academic journals from government to help them achieve their goals.

\section{Conclusion}

Although a number of Philippine journals have been included in the TR and Scopus master journal lists and citation databases, in general their readership and citation impact factors are low. Similar to initiatives in other countries regarding their science journals, efforts and financial support must be intensified by the Philippine government and all concerned sectors to support the improvement and modernization of its scien- 


\section{science editing /}

tific and academic journals to enable them to attain international standards.

\section{Conflict of Interest}

No potential conflict of interest relevant to this article was reported.

\section{Acknowledgments}

The author acknowledges with thanks Prof. Fabian M. Dayrit, Ateneo University and Prof. Allan B.I. Bernardo, University of Macau, for various information and insights they kindly shared; to the National Academy of Science and Technology Philippines for convening the Philippine science editors meeting; and to Ms. Rowena V. Briones of the NAST Secretariat for her help to arrange meetings and obtaining various data for this paper.

\section{References}

1. Tecson-Mendoza EM. The Philippine Agriculturist and Forester/Agriculturist/Agricultural Scientist (1911-2010): chronicler of the UP College of Agriculture and Philippine agricultural development. Philipp Agric Sci 2011;94(Special Issue):S1-8.

2. Acta Medica Philippina: the national health science journal [Internet]. Manila: Acta Medica Philippina [cited 2015 Jul 13]. Available from: http://actamedicaphilippina.com. $\mathrm{ph} /$

3. Taro FA. An index to the Philippine Journal of Education, volume 1-31 (1918-1953) [dissertation]. Diliman: University of the Philippines; 1954.

4. Dayrit FM. The role of publications in the assessment of higher education institutions in the Philippines. Paper presented at: Asian Science Editors' Conference and Workshop 2014; 2014 Jul 2-4; Seoul, Korea.

5. Tecson-Mendoza EM. Philippine scientific journals face increasing challenges. Paper presented at: Asian Science Editors' Conference and Workshop 2014; 2014 Jul 2-4; Seoul, Korea.

6. Thomson Reuters. Master journal list [Internet]. Philadelphia, PA: Thomson Reuters [cited 2015 Jun 30]. Available from: http://ip-science.thomsonreuters.com/mjl/

7. Elsevier. Scopus journal title list [Internet]. Amsterdam: Elsevier [cited 2014 Apr 17]. Available from: http://www. elsevier.com/solutions/scopus/content

8. Commission on Higher Education. Guidelines for CHED accreditation of research journals and providing incentives therefor [Internet]. Quezon City: Commission on Higher Education; 2009 [cited 2015 Jul 24]. Available from: http:// www.ched.gov.ph/wp-content/uploads/2013/07/CMONo.13-s2009.pdf

9. Ilieva J. Research collaboration in selected ASEAN countries. Study supported by the British Council and Global Education Dialogues. Paper presented at: Hong Kong 2012; 2012 Sep 29; Hong Kong.

10. Lammey R. CrossRef developments and initiatives: an update on services for the scholarly publishing community from CrossRef. Sci Ed 2014;1:13-8. http://dx.doi.org/ 10.6087/ kcse.2014.1.13

11. Jeong GH, Huh S. Increase in frequency of citation by SCIE journals of non-Medline journals after listing in an open access full-text database. Sci Ed 2014;1:24-6. http:// dx.doi.org/10.6087/kcse.2014.1.24

12. Commission on Higher Education. CHED accredited research journals [Internet]. Quezon City: Commission on Higher Education; 2013 [cited 2015 Jul 15]. Available from: http://www.ched.gov.ph/wp-content/uploads/2013/ 05/CMO-No.-26-s2013.pdf

13. Huh S. Current challenges of the scientific publishing community in Korea [Internet]. Trevose, PA: Editage Insights; 2014 [cited 2015 Jul 15]. Available from: http:// www.editage.com/insights/current-challenges-of-the-scientific-publishing-community-in-korea\# 